\title{
Effects of Nutritional Factors on Regular Cropping of Apple
}

Warren C. Stiles

AdDITIONAL INDEX WORDS. flower development, fruit set, nutrient elements, yield

Summary. $\mathrm{N}$ utritional status of apple (Malus domestica Borkh.) trees may influence regularity of cropping through effects of some nutrient elements at various stages of the floral initiation, development, pollination, fertilization and fruit setting process. 0 ther elements may influence regularity of cropping more indirectly as consequences of their effects on physiological processes or by modifying the sensitivity of the tree to adverse environmental factors. This report provides a brief summary of reported impacts of mineral nutrition on regularity of cropping.

$\mathrm{R}$

egularity of crop production is influenced by numerous factors within the orchard management system and its environment. Biennial bearing or irregular cropping of apple cultivars is usually the consequence of frost-freeze damage, overcropping, inappropriate pruning practices, drought, and sometimes nutritional problems. In this context, the purpose of nutrition management is to ensure that deficiency or toxicity of essential nutrient elements do not impose limitations on floral induction, flower development, pollination, fertilization, or fruit set. A review of this topic by Chaplin and Westwood (1980) provides a summary of some of these relationships.

While some elements may be shown to be directly involved in one or more of these processes, the roles of other elements are more likely to be indirect. Indirect effects involve modification of the sensitivity of trees to adverse environmental factors and physiological processes that impact cropping. This presentation will attempt to summarize some of the nutritional effects on various aspects of the cropping cycle in apples. O bservations and unpublished results of experiments conducted by the author will be included where appropriate. Those who desire more comprehensive general reviews of literature on apple nutrition may wish to consult the reviews by Boynton and O berly (1966), or Sadhu (1988).

Nitrogen has both direct and indirect effects on regularity of cropping. The direct effects attributed to nitrogen include those on flower initiation and development, length of the period of ovule receptivity, and fruit set. The indirect effects of nitrogen are those related to relative vigor of the trees as indicated by shoot and spur growth, and leaf area to support photosynthesis and the production of carbohydrate reserves.

D epartment of Fruit and Vegetable Science, Cornell U niversity, I thaca, NY 14853.

The cost of publishing this paper was defrayed in part by the payment of page charges. U nder postal regulations, this paper therefore must be hereby marked advertisement solely to indicate this fact. 
D eficiency of nitrogen (less than $\approx 1.5 \%$ in midsummer shoot leaves) may prevent flower bud formation, but such conditionsare not a common occurrence in well managed commercial orchards.

A low nitrogen status (less than $\approx 2.0 \%$ ) may be associated with development of heavy snowball blooms. Thissituation is often found during off years in biennial bearing trees. U nder these conditions, the flowers tend to be relatively smaller and weaker than normal. Fertilization of the flowers is often poorer than might be expected. Postbloom fruit drop is accentuated, treesare sensitiveto chemical thinners, and final fruit set may berelatively low.

A high nitrogen status (mo rethan $\approx 2.4 \%$ ) can be associated with excessive vegetative growth and poor flower bud initiation in shaded interior portions of the trees. H owever, as indicated by Chandler (1925) "with trees old enough to bear profitable crops, it is not generally possible, by use of nitrogen alone, to prevent excessive formation of fruit buds, if during J une and J uly there are several weeks of high transpiration and rather low soil moisture" .

Oland (1963) reported significant yield increases in both on and off years of ' $G$ ravenstein' trees growing in sod that had received postharvest sprays of urea. In this study, the urea sprays increased the $\mathrm{N}$ content of spur buds asmeasured from $\mathrm{N}$ ovember into February. L eaf $\mathrm{N}$ content of trees receiving no nitrogen or soil applications of calcium nitrate was below $2 \%$

Williams (1965) demonstrated that improving the "strength" of flower buds by late summer nitrogen applications can improve fruit set by increasing the length of the effective pollination period in apples.

Tami et al. (1986) found that leaf $\mathrm{N}$ was positively correlated with percent floral buds and with fruit yield in the second year of soil applications of urea to 10-year-old 'Starkspur Golden D elicious' trees. In the first year, fruit set was increased $11 \%$ by the urea treatment. Floral bud initiation during the second year of treatment was increased by $7 \%$. Crop density (fruit per limb cross-sectional area) wasincreased in both years, but this increase was not statistically significant.

Fallahi (1997) observed lower yields of 'R edspur $D$ elicious' from trees that had received low annual N [ 1.6 oz/ tree $(45.3 \mathrm{~g} /$ tree)] applications, but no significant difference in yields among trees that received $\mathrm{N}$ at 6.4 to $20.8 \mathrm{oz} /$ tree ( 181.4 to $589.6 \mathrm{~g} /$ tree). Fruit $\mathrm{N}$ concentration tended to increase with increasing rate of $\mathrm{N}$ application. A pparently, the lowest rate of $\mathrm{N}$ application was not adequate to sustain consistent cropping in this study.

O ur present recommendation for nitrogen management (Stiles and Reid, 1991) includes the application of a prebloom urea spray when the previous season analysis shows leaf nitrogen values of $<2.4 \%$ This is considered to be critical for those varieties that are being managed at relatively low nitrogen levels to favor development of fruit color and improve storage quality.

I t isgenerally accepted that excess nitrogen increasessusceptibility of buds to cold injury. Incidence and severity of fireblight (Erwinia amylovora Burr) is also increased by excessive application of nitrogen fertilizers (van der Zwet and Beer, 1991). H igh nitrogen status also enhances prospects of increased damage to leaves by pests such asEuropean red mite(Panonychusulmi Koch) (Smith et al., 1989). Thesetypes of problems can have significant impacts on fruit set and regularity of cropping.

Phosphorus application to established orchards have generally not resulted in economically significant benefits on cropping of apple trees. $\mathrm{N}$ eilsen et al. (1990) found that application of monoammonium phosphate (M AP) in theyear of planting increased leaf $P$, blossoming and fruit set the next year on trees planted in nonreplant soil. In subsequent field trials in eight replant situations with various planting time treatments, only three orchards had significantly higher cumulative blossom numbers, and only one orchard had increased yield by the end of the third growing season ( $\mathrm{N}$ eilsen, 1994).

No economic response of newly planted or established trees to P applications were found in several experiments conducted in N ew York State (O berly, 1989; Stiles, 1994). H owever, in some cases there have been responses to M AP that are associated with its strong soil acidification effect in increasing availability of $\mathrm{M} \mathrm{n}$ or $\mathrm{M} \mathrm{g}$. Similar effects of MAP in increasing availability of $\mathrm{Mn}$ have also been reported by N eilsen (1994).
Potassium affects cropping indirectly through effects on tree vigor. Shortage of potassium results in reduced vegetative vigor along with reduced fruit size and color. H owever, flowering and fruit set areusually abundant with mild potassium deficiency, but decrease and may be eliminated as severity of the deficiency increases. Yield may be limited by potassium shortage through its effect on tree growth and vigor, at levelswell above those associated with visual deficiency symptoms.

Results from a fertigation study (Stiles, 1998) initiated with trees planted in 1993 and deblossomed during the first two seasons showed a significant increase in shoot growth in response to $\mathrm{K}$. Yields during the first three cropping seasons were related positively with shoot growth during the first two growing seasons ( $T$ able $1)$. In this trial, the lowest rate of $K$, $33.2 \mathrm{lb} /$ acre $\left(42 \mathrm{~kg} \cdot \mathrm{ha}^{-1}\right)$ per year has been enough to meet the requirements of these young trees in terms of shoot growth, yield and maintaining leaf $K$ in our suggested sufficiency range of $1.35 \%$ to $1.80 \%$. H owever, since $\mathrm{K}$ requirement is directly related to crop load it is anticipated that these relationships may change as the trees mature.

An additional factor to consider, particularly in areas subject to spring frosts, is that cold damage to blossoms may be accentuated by inadequate $K$. This aspect is illustrated by data reported by $\mathrm{H}$ eeney (1968) that shows the impact of both $\mathrm{K}$ and $\mathrm{Zn}$ on damage to apple flowers as a consequence of a spring frost. L eaf $K$ levels of $1.5 \%$ to $1.7 \%$ and a $\mathrm{Zn}$ level of $55 \mathrm{ppm}$ $\left(\mathrm{mg} \cdot \mathrm{L}^{-1}\right)$ were associated with minimal frost kill of blossoms. Frost damage increased with lower concentrations of either $\mathrm{K}$ or $\mathrm{Zn}$.

Magnesium has both direct and indirect effects. With $\mathrm{Mg}$ deficiency, vigor of shoots is reduced and spurs tend to be thin, weak and brittle. Although not generally affected, flowering may be reduced if excessive leaf drop occurs early in the season. Early leaf drop from $\mathrm{M} g$ deficiency frequently also leads to blind wood as a result of poor lateral bud development on current season extension growth.

Fisher et al. (1958) reported increased yields over 4 years after correcting magnesium deficiency with applications of dolomitic limestone.

Greenham and White (1959) 
T able 1. Potassium effect on shoot growth, yield, and leaf $K$, 'M cl ntosh'/M alling 9 (Source: Stiles, 1998).

\begin{tabular}{|c|c|c|c|}
\hline $\begin{array}{l}\text { Annual } \\
\text { K rate } \\
\text { (lb/acre) }^{x}\end{array}$ & $\begin{array}{c}\text { Shoot growth } \\
1993+1994 \\
\text { (ft/tree) }^{y}\end{array}$ & $\begin{array}{c}\text { Yield } \\
\text { 1995-97 } \\
\text { (Ib/tree) }^{z}\end{array}$ & $\begin{array}{c}\text { L eaf K } \\
1997 \\
\text { (\% dry wt) } \\
\end{array}$ \\
\hline 0 & $4.07 \mathrm{a}$ & $42.8 \mathrm{a}$ & $1.03 \mathrm{a}$ \\
\hline 33.2 & $5.25 \mathrm{~b}$ & $58.4 \mathrm{~b}$ & $1.51 \mathrm{~b}$ \\
\hline 66.4 & $5.51 \mathrm{~b}$ & $58.3 b$ & $1.43 \mathrm{~b}$ \\
\hline 99.6 & $5.09 \mathrm{~b}$ & $57.2 \mathrm{~b}$ & $1.50 \mathrm{~b}$ \\
\hline Significance & e $p=0.05$ & $p=0.05$ & $p=0.05$ \\
\hline
\end{tabular}

${ }^{\mathrm{x}} 1 \mathrm{lb} / \mathrm{acre}=1.12 \mathrm{~kg} \cdot \mathrm{ha}^{-1}$.

$\mathrm{y}_{1} \mathrm{ft} / 0.3 \mathrm{~m}$.

z $1 \mathrm{lb} / 2.2 \mathrm{~kg}$

showed that postbloom Epsom salts $\left(\mathrm{M} \mathrm{gSO}_{4} \cdot 7 \mathrm{H}_{2} \mathrm{O}\right)$ spraysapplied to $\mathrm{M} \mathrm{g}$ deficient 'E dward VII'/ M alling 7 trees over a 5-year period did not increase thenumber of fruit buds produced but did improve fruit set by an average of $68 \%$ Crop production per tree was increased significantly in 2 of the 5 years and total crop for the 5-year period was $80 \%$ greater with the Epsom salts sprays. Leaf $\mathrm{Mg}$ levels for control trees were deficient $(0.11 \%$ to $0.19 \%$ ) and Epsom salts sprays increased these to $0.18 \%$ to $0.34 \%$ The effects of the Epsom salts sprays was greatest during the 2 years when fruit set was poorest on the control trees.

In this same study, urea sprays also increased average fruit set by $27 \%$ and total crop by $36 \%$, possibly because of a direct nitrogen effect on fruit setting or of a magnesium mobilization role.

$M$ agnesium deficient trees will respond positively to foliar applications of magnesium, but little or no benefit should be expected if the magnesium status of the trees is adequate. O ur current interpretation of adequacy is a $\mathrm{Mg}$ level of $0.35 \%$ to $0.50 \%$ and/ or a $\mathrm{K}$ to $\mathrm{M} \mathrm{g}$ ratio smaller than $\approx 4: 1$ in leaf samples collected 60 to $70 \mathrm{~d}$ after petal fall (Stiles and Reid, 1991).

Boron influences cropping in a variety of ways. Boron deficiency has been shown to result in reduced flowering; abnormal development of flowers; reduced pollen development and germination; and severe reduction of fruit set. When severe, boron deficiency results in death of meristematic tissues and poor development of conducting tissues(Stilesand Reid, 1991).

Several reports indicate beneficial effects of foliar applications of boron, either postharvest or before bloom, in increasing fruit set of apples. Other reports indicate no response, or in a few cases, reductions in fruit set. These differences would appear to be attributable to differences in the boron status of the buds and/ or differences in boron requirementsin specific situations. I t hasbeen suggested that improvement in fruit set may be related to correction of incipient boron deficiencies.

D avison (1971) reported fruit set increases of $6 \%$ to $29 \%$ in 11 trials when boron sprays were applied at open cluster (pink) and again at $80 \%$ to $100 \%$ petal fall.

Generally, midsummer leaf sample contents of 35 to $50 \mathrm{ppm}\left(\mathrm{mg}^{\circ} \mathrm{L}^{-1}\right) \mathrm{B}$ are considered to be adequate. Woodbridge et al. (1971) found relatively high levels of $B$ in developing buds of apple, pear (Pyrus communis L.), and cherry (Prunus avium L.). These authorsreported that both total $B$ per bud and concentration of $B$ on a dry weight basis increased gradually as buds enlarged and rapidly as the flowers opened to full bloom. The levels in floral partsreached their maxima when pollination and fertilization occurred and then total B decreased sharply when the petals fell.

Boron toxicity can cause abnormal flower development and reduced cropping. $\mathrm{H}$ ansen (1981) found excessive boron to result in delayed development of buds and bloom, reduced blossom density, and reduced yields. D elayed bud development and bloom were associated with previous season leaf $B$ levels of 40 to $50 \mathrm{ppm}$ $\left(\mathrm{mg} \cdot \mathrm{L}^{-1}\right)$, and bloom density was reduced or buds failed to develop normally at leaf $B$ levels of 60 to 70 ppm.

There is a need for more information about the optimal level of B in buds and particularly in reproductive tissues during the flowering and fruit set period as these relate to fruit set and regularity of cropping.

Manganese. M ild deficiencies of manganese do not appear to influence cropping. In this author's experience, application of manganese-containing fungicides or sprays of manganese sulfate that provide sufficient manganese to prevent appearance of deficiency symptoms has been adequate to avoid effects on cropping. H owever, D unne(1946) reported reduced cropping under severe $\mathrm{M} n$ deficiency conditions in Australia.

$M$ aintaining midsummer leaf contents of at least 35 to 150 ppm $\left(\mathrm{mg} \cdot \mathrm{L}^{-1}\right) \mathrm{Mn}$ should minimize the possibility of adverse effects from $M n$ deficiency. Leaf levels considerably higher than this can result from applications of manganese-containing fungicides or other foliar sprays but usually do not indicate toxicity.

Zinc. Flowering and cropping are reduced by zinc deficiency and may be eliminated under severe deficiency (Stiles and Reid, 1991). Zinc deficiency reducesgrowth and general tree vigor and if severe it can result in dieback of shoots or limbs. This effect is often not uniform throughout the tree but may be more severe on individual limbs than on others. There is always a reduction in the number of flower buds on severely affected trees (Chandler, 1937).

0 ver a3-year period, averageyield of ' $\mathrm{M} \mathrm{Cl}$ ntosh' trees receiving annual mid-June postbloom foliar sprays of EDTA-zinc chelate was increased by $30 \%$ A single application of EDTAzinc at the pink stagelikewise increased yield of ' $\mathrm{M}$ cl ntosh' by $17 \%$ over a 2 year period (Stiles, 1980).

O ne of the difficulties in assessing zinc status is determining when to sample. Thus, N eilsen (1988) showed that midshoot leaf $Z n$ declined from a high of $40 \mathrm{ppm}\left(\mathrm{mg} \cdot \mathrm{L}^{-1}\right)$ in early $M$ ay to values approaching or below 14 ppm (mg $\left.\mathrm{L}^{-1}\right)$ by midsummer.

Cultivar differences in zinc requirements and responseto zinc applications seem to be related inversely to the phosphorus levels found in leaf tissues. Thus, 'M cl ntosh' does not

T able 2. E ffect of copper sprays on 'I dared' apple, I thaca, N.Y., 1987 (Source: Stiles, unpublished data).

\begin{tabular}{|c|c|c|c|}
\hline T reatment $^{2}$ & $\begin{array}{l}\text { Yield } \\
\text { ons/acre) }\end{array}$ & $\begin{array}{l}\text { Fruit diam } \\
\text { (inches) }^{\mathrm{x}}\end{array}$ & $\begin{array}{l}\text { Leaf Cu } \\
(\mathrm{ppm})^{\mathrm{w}}\end{array}$ \\
\hline $\mathrm{N}$ ontreated & 8.25 & 2.976 & 5.49 \\
\hline Kocide & 8.25 & $3.060^{*}$ & 5.68 \\
\hline Kocide + oil & $11.28^{*}$ & $3.048^{*}$ & $6.04^{*}$ \\
\hline $\begin{array}{l}\text { EDTA-Cu } \\
\text { EDTA-Cu }\end{array}$ & $11.15^{*}$ & 2.948 & 5.58 \\
\hline +oil & $10.43^{*}$ & 3.008 & 5.49 \\
\hline
\end{tabular}

${ }^{\mathrm{z}}$ T reatments applied at $1 / 4$-inch $(0.6-\mathrm{cm})$ green stage.

y1 ton/ acre) $=2.24 \mathrm{t} \cdot \mathrm{ha}^{-1}$

$\times 1$ inch $=2.54=\mathrm{cm}$.

${ }^{w}$ ppm $=m g \cdot L^{-1}$

*Significantly different from nontreated at $p=0.05$. 
exhibit deficiency symptoms as readily as 'D elicious', which generally has a higher leaf phosphorus content.

Following winter injury to buds, foliar application of a combination of boron plus EDTA- $\mathrm{Zn}$ chelate at 1 / 2inch $(1.25 \mathrm{~cm})$ green followed by boron plusEDTA-Zn chelateplusureaat tight cluster to pink hasbeen helpful in improving bud survival and fruit set (Stover et al., 1999).

Copper deficient trees may exhibit poor shoot growth or dieback of shoots, reduced bloom and poor fruit set. As with zinc, $\mathrm{Cu}$ levels in bud tissues may be fairly high at the beginning of growth, but the level in leaf tissues declines rapidly as growth proceeds. R egression analysis of yield data from various experiments suggest a midsummer leaf level of 7 to $12 \mathrm{ppm}$ ( $\mathrm{mg} \cdot \mathrm{L}^{-1}$ ) to beoptimal (Stilesand Reid, 1991). H owever, little information is available concerning optimal requirements during bud development and bloom.

Foliar application of copper at the $1 / 4$-inch $(0.6 \mathrm{~cm})$ green stage of development hs improved yield and size of fruit, but may show little effect on midsummer leaf levels of co pper ( $T$ able 2).

Spray applications of co pper compounds must be applied before florets are exposed in the buds or after harvest if injury to the fruit is to be avoided. Very low rates of copper applied after 1/ 4-inch to 1/ 2-inch green or in early postbloom sprays can cause serious fruit russeting.

\section{Comments}

$\mathrm{N}$ utrition is an important factor in maintaining regular cropping in apples. The primary objective in managing nutrition should be to avoid either deficiency or toxicity situations that might interfere with normal plant function. Interactive relationships of cropping and environmental factors with nutritional factors must be recognized and appropriate adjustments made in order to optimize tree performance and regularity of cropping.

\section{Literature cited}

Chandler, W.H . 1925. Fruit growing. G.A. Works and W.S. Taylor (eds.). H oughton $M$ ifflin, N ew York.

Chandler, W.H . 1937. Zinc asa nutrient for plants. Bot. Gaz. XCVIII (4):625-646.

Chaplin, M.H . and M.N. Westwood. 1980. Relationship of nutritional factors to fruit set. J. Plant N utr. 2(4):477-505.

Boynton, D. and G.H . O berly. 1966. Apple nutrition, p. 1-50. In: N.F. Childers (ed.). $\mathrm{N}$ utrition of fruit crops. H ort. Publ., Rutgers U niv., N ew Brunswick, N.J.

D avison, R.M . 1971. Effect of early season sprays of trace elements on fruit setting of apples. N .Z. J. Agr. Res. 14:931-935.

Dunne, T.C. 1946. M anganese deficiency of appletrees. J. W. Austral. D ept. Agr. (Ser. 2) 23:127-130.

Fallahi, E. 1997. Preharvest nitrogen optimization for maximizing yield and postharvest fruit quality of apples. Acta $\mathrm{H}$ ort. 448:415-419.

Fisher, E.G., D.R. Walker, D. Boynton, and S.S. K wong. 1958. Studies on the control of magnesium deficiency and its effect on apple trees. Proc. Amer. Soc. H ort. Sci. 71:1-10.

Greenham, D.W.P. and G.C. White. 1959. Control of magnesium deficiency in dwarf pyramid apples. J. H ort. Sci. 34:238-247.

$\mathrm{H}$ ansen, Poul. 1981. Boron toxicity and bud development in apple trees. Danish J. Plant Soil Sci. 85:405-410.

H eeney, H .B. 1968. N utrition and itsinfluence on fruit storage and winter hardiness of apples. Proc. 74th Annu. M tg. M ass. Fruit Growers' Assn. 74:71-81.

N eilsen, G.H . 1988. Seasonal variation in leaf zinc concentration of apples receiving dormantzinc. H ortScience23(1):130-132.

Neilsen, G.H., E.J. Hogue, and P.P archomchuk. 1990. Flowering of appletrees in the second year is increased by first-year $P$ fertilization. HortScience 25(10):12471250 .

Neilsen, G.H. 1994. Phosphorus on replanted orchards, p. 71-77. In:A.B. Peterson and R.G. Stevens(eds.). T reefruit nutrition. Good Fruit Grower, Yakima, Wash.

O berly, G.H . 1989. Apples, p. 305-316. In: D.L. Plucknett and H.B. Sprague (eds.).
Detecting mineral nutrient deficiencies in tropical and temperatecrops. Westview Press, Boulder, Colo.

O land, K. 1963. Responses of cropping apple trees to post-harvest urea sprays. $\mathrm{Na}$ ture 198:1282-1283.

Sadhu, M.K. 1988. Apple, p. 444-510. In: T.K. Bose, S.K. Mitra, and M.K. Sadhu (eds.). M ineral nutrition of fruit crops. $\mathrm{N}$ aya Prokash, Calcutta, India.

Shear, C.B. and M . Faust. 1980. N utritional ranges in deciduous fruits and nuts. $\mathrm{H}$ ort. Rev. 2:142-163.

Smith, G.D., W.C. Stiles, and R.W. Weires. 1989. The effects of ground cover manipulations on pest and predator mite populations on apple in eastern N ew York. N.Y. State Agr. Expt. Sta. (Geneva) Food Life Sci. Bul. 128.

Stiles, W.C. 1980. Pruning, growth regulator, and nutrition studieswith apples. Annu. Rpt. M aine State Pomol. Soc. p. 25-34.

Stiles, W.C. 1994. Phosphorus, potassium, magnesium, and sulfur soil management, $p$. 63-70. In: A.B. Peterson and R.G. Stevens (eds.). Tree fruit nutrition. Good Fruit Grower, Yakima, Wash.

Stiles, W.C. 1998. Orchard nutrition research. N ew York Fruit Q uart. 6(2):8-10.

Stiles, W.C. and W.S. Reid. 1991. Orchard nutrition management. Cornell U niv. Coop. Ext. I nfo. Bul. 219.

Stover, E.W., M.J. Fargione, W.C. Stiles, and K.A. I ungerman. 1999. Effect of prebloom boron, zinc, and urea applicationson spur leaf development, fruit set, and cropping of 'Empire' and 'M cl ntosh' apple. $\mathrm{H}$ ortScience (in press).

Tami, M ., P.B. L ombard, and T .L . Righetti. 1986. Effect of urea nitrogen on fruitfulness and fruit quality of Starkspur Golden Deliciousappletrees. J. Plant N utr. 9(1):75-85.

van der Z wet, T. and S.V. Beer. 1991. Fire blight-I tsnature, prevention, and control. U SD A Agr. Info. Bul. 631.

Williams, R.R. 1965. The effect of summer nitrogen applications on the quality of apple blossom. J. H ort. Sci. 40:31-41.

Woodbridge, C.G., A. Venegas, and P.C. Crandall. 1971. The boron content of developing pear, appleand cherryflower buds. J. Amer. Soc. H ort. Sci. 96(5):613-615. 